\title{
Survival of purebred and hybrid Serrasalmidae under low water temperature conditions
}

\author{
Erica Machado Fernandes ${ }^{\mathrm{a}}$, Luis Carlos Ferreira de Almeida ${ }^{\mathrm{b}}$, Diogo Teruo Hashimoto ${ }^{\mathrm{a}}$, \\ Gabriel Rinaldi Lattanzi ${ }^{\mathrm{b}}$, Washington Rocha Gervaz ${ }^{\mathrm{b}}$, Antônio Fernando Leonardo ${ }^{\mathrm{c}}$, \\ Rafael Vilhena Reis Neto ${ }^{\mathrm{b}, *}$ \\ ${ }^{a}$ UNESP Aquaculture Center (CAUNESP). Access way Prof. Paulo Donato Castellane, s/n 14884-900-, Jaboticabal, SP, Brazil \\ ๖ State University of São Paulo “Júlio de Mesquita Filho" (UNESP) - Campus of Registro, Avenue Nelson Brihi Badur 430, 119000-000 Registro, SP, Brazil \\ ${ }^{\mathrm{c}}$ São Paulo Agribusiness Technology Agency (APTA) - Regional Polo of Vale do Ribeira, Highway BR 116, km 460, PO Box 122, 1900-000, Brazil
}

\section{A R T I C L E I N F O}

\section{Keywords:}

Cold tolerance

Colossoma macropomum

Piaractus mesopotamicus

Survival curves

\begin{abstract}
A B S T R A C T
The aim of the study was to evaluate the survival of Serrasalmidaes fish, pure and hybrid, during periods of low temperature. The experiment was carried out from June to August 2016 (51 days) in an aquaculture station of São Paulo Agribusiness Technology Agency, Brazil. A diallel crossbreeding between pacu and tambaqui was performed by artificial reproduction, generating four genetic groups: pacu ( $\sigma^{x}$ pacu $\times \subsetneq$ pacu), tambaqui $\left(\sigma^{x}\right.$ tambaqui $\times \propto$ tambaqui), paqui ( $\sigma^{\prime \prime}$ tambaqui $\times \propto$ pacu), and tambacu ( $\sigma^{\prime \prime}$ pacu $\times \propto$ tambaqui). Fish were distributed in 24 experimental plots (110 fingerlings of each groups per plot) and were fed twice daily with commercial diets containing three different levels of crude protein (CP): $24 \%, 28 \%$ and $32 \%$. When the water temperature showed successive decreases due to the environmental climatic conditions, the ponds were monitored daily to record the mortality. The data on number of days of life of animals were submitted to Cox multivariate regression analysis to test the effects of the genetic group, $\mathrm{CP}$ levels and the interaction between the two factors. Kaplan-Meier survival curves were adjusted for factors that had a significant effect on the Cox regression analysis. The pacu group presented higher survival than other groups, regardless of the CP level in the diet. The tambaqui and paqui groups were more susceptible to environmental conditions, especially when fed a diet containing a higher level of CP. Overall, purebred pacu presented greater adaptation to the production conditions in the region where the experiment was carried out. However, if the aim is the production of hybrid fish, crosses between pacu males and tambaqui females (Tambacu) generate fish that are resistant to low temperatures.
\end{abstract}

\section{Introduction}

Since fish are ectotherms and their body temperature is dependent on their environment, water temperature is one of the most important variables in fish farming (Kellogg and Gift, 1983; McCauley and Beitinger, 1992). Ponds and cages designed for fish farming are generally shallow and limited, which restricts the ability to escape, allowing fish to be directly influenced by climatic conditions and handling (Sipaúba-Tavares et al., 1999). The ideal temperature range for tropical fish growth is $25^{\circ} \mathrm{C}$ to $32^{\circ} \mathrm{C}$ and, in the warmer seasons of the year, food consumption increases (Dayton et al., 1995; Dobson and Holmes, 1984). However, temperatures exceeding the optimal level for the species hinder digestion processes, inhibiting the absorption of nutrients, reducing growth rates and, in extreme cases, may be lethal (Azevedo et al., 2011; Jobling and Baardvik, 1994). In contrast, low temperatures reduce metabolic activity, decrease the immunity of the animals and favor the emergence of diseases that are triggered mainly by bacteria and fungi (Sardella et al., 2007).

Freshwater fish, such as salmonids, carp (Cyprinus carpio), catfish (including Pangasius) and tilapia (Oreochromis $s p$ ), have dominated the world market of continental aquaculture (FAO, 2016). However, recent studies on native species and some hybrids from South America showed high yield potential (Hashimoto et al., 2012; Neto et al., 2012). Among the species of high potential, representatives of Serrasalmidae family, mainly pacu Piaractus mesopotamicus, tambaqui Colossoma macropomum, and their interspecific hybrid fish have been mass-produced in

\footnotetext{
* Corresponding author.

E-mail addresses: luiscarlos@registro.unesp.br (L.C.F. de Almeida), diogo@caunesp.unesp.br (D.T. Hashimoto), afleonardo@apta.sp.gov.br (A.F. Leonardo), rafaelneto@registro.unesp.br (R.V.R. Neto).
} 
Brazilian and South American aquaculture (Filho, 2016).

Tambaqui is widely distributed in tropical regions of South America and Central Amazonia. In Brazil, it is the second most cultivated species in terms of continental aquaculture with a production over 135 thousand tons (Filho, 2016). Although cultivation is possible throughout the Brazilian territory, fish farmers are discouraged from cultivating tambaqui due to high mortality rates during the winter, especially in the south and southeast regions of Brazil, where there are long periods with low temperatures during this season. On the other hand, pacu show tolerance to low temperatures, which represent normal conditions for the Southeast and South of the country, but have lower growth compared with tambaqui (Reis Neto et al., 2012). Thus, hybrids are produced from the crossing of pacu and tambaqui to obtain a fish that has better performance than the parental species with regard to growth rate, fillet quality, resistance to diseases, and cold tolerance, among other factors.

Although these species and their hybrids belong to the same family (Serrasalmidae), the nutritional requirements of the fish can vary according to the life stage, genetic constitution, physiological state, seasonality, production system, water quality and temperature (Hidalgo et al., 1987). Determination of protein and energy requirements is essential for any initiative aimed at the cultivation of a certain species, since protein is the main nutrient used in fish diets and also represents the greatest economic cost in intensive cultivation ( $\mathrm{Ng}$ et al., 2000).

Inadequate nutritional management can be harmful to health, causing the fish to become more susceptible to environmental variations and increasing the occurrence of diseases and even mortality. Several research studies have already been carried out to determine adequate levels of protein in the diet for the best growth of pacu and tambaqui. For pacu juveniles, the level of $27 \%$ CP results in higher growth rates (Bicudo et al., 2010), while for tambaqui, the CP levels that favor growth are approximately $30 \%$ (Lima et al., 2016). However, there are no studies available which have evaluated the influence of protein level in the diet on the tolerance of Serrasalmidae fish to low temperatures.

The production of hybrids from the crossing pacu and tambaqui is very common in South American fish farms. However, there are no scientific reports confirming the improved adaptation to environmental variations compared to their parental species. Therefore, we evaluated the survival of pacu, tambaqui and their reciprocal hybrids when they were fed diets containing different levels of protein, during periods of low water temperatures in fish farm ponds.

\section{Materials and methods}

\subsection{Genetic groups}

The experiment was carried out from 10 June to 01 August 2016 in Pariquera-Açú (latitude $24^{\circ} 43$ ' 14 ' 'S and longitude $47^{\circ} 52$ ' 43 ' $\mathrm{O}$ ), in the fish farming sector of APTA Vale do Ribeira of the Paulista Agribusiness Technology Agency (APTA Regional).

The juveniles used in the experiment came from breeding stock from the Aquaculture Center of State University of São Paulo (CAUNESP Jaboticabal). Molecular analysis was performed to confirm the breeds of the parental species (pacu and tambaqui). For this purpose, fin samples were collected from the animals selected for reproduction and fixed in $100 \%$ ethanol, and subsequently methods of extraction and purification of the total DNA based on the commercial kit "Wizard Genomic DNA Purification Kit - Promega" were applied. Afterwards, Multiplex PCR (tpm1 gene), standardized according to protocols developed by the Fish Genetics Laboratory of UNESP of Bauru, was used for the molecular identification and analysis of the samples (Hashimoto et al., 2014). The products generated by Multiplex-PCR were subjected to agarose gel electrophoresis, generating a pattern of diagnostic genotypes that was used to identify purebred fish and possible interspecific hybrids (Fig. 1).
After confirmation of the breeding species by molecular analysis, a diallel cross between pacu and tambaqui was carried out in the native fish breeding laboratory at the UNESP Aquaculture Center (CAUNESP Jaboticabal). In December 2015, five pacu males, four tambaqui males, five pacu females and four tambaqui females were used in the artificial reproduction protocol developed by Criscuolo-Urbinati et al. (2012). Oocytes from each female (50 g, approximately 1200 oocytes $/ \mathrm{g}$ ) were fertilized separately with semen (500 ul) from each male. The use of pool before fertilization was not applied to avoid differences due to the spermatozoa/oocyte quality of each male/female. The eggs of each genetic group were clustered in different incubators of 1001 after $15 \mathrm{~min}$ of fertilization, before the larvae hatching. This strategy was adopted due to the limitations of the number of incubators and physical space, i.e., incubating the eggs separately from each mating was not feasible. This generated four genetic groups: pacu (pacu female and pacu male); tambaqui (tambaqui female and tambaqui male); paqui (pacu female and tambaqui male); and tambacu (tambaqui female and pacu male).

The embryos were incubated as separate genetic groups. After hatching, the larvae were fed with Artemia Salina Artemia franciscana nauplii and after five days were transferred to ponds at a density of 200 larvae $/ \mathrm{m}^{2}$, with one genetic group in each pond.

\subsection{Experimental conditions and survival study}

In February of 2016, 2640 fingerlings of each genetic group were transferred to the fish farm at the regional APTA of Vale do Ribeira and stocked in twelve $200 \mathrm{~m}^{2}$ ponds, each divided into two equal parts $(5 \times 20 \mathrm{~m})$ separated by a polypropylene screen $(9 \times 9 \mathrm{~mm}$ mesh) with individual water supplies, forming 24 experimental plots.

The twelve ponds used have exactly the same measurements: $20 \mathrm{~m}$ in length, $10 \mathrm{~m}$ in width and initial and final depth in $1.2 \mathrm{~m}$ and $0.5 \mathrm{~m}$ respectively, in addition they were arranged in the same direction and very close to each other. Although each pond had an independent supply and drainage system, the water source (dam) was the same for all ponds, which minimizes the effect of the plot.

The 660 fingerlings of each genetic group (initial weight: pacu $=11.1 \pm 4.6 \mathrm{~g} ;$ tambaqui $=15,3 \pm 6.8 \mathrm{~g} ;$ tambacu $=14.5 \pm$ $5.6 \mathrm{~g}$; paqui $=9.7 \pm 4.2 \mathrm{~g}$ ) were randomly collected and distributed in the experimental plots (110 fingerlings from each group per plot).

Feeding consisted of three diets containing CP levels of $24 \%, 28 \%$ and $32 \%$, provided ad libitum, twice daily, with the exception of days when the water temperature fell to values below $20^{\circ} \mathrm{C}$.

As of June 10, when the water temperature showed successive drops, the ponds were monitored daily and fish that were found dead were recorded according to their experimental plots, at this time survival was $100 \%$ for all groups. Thus, the survival time of each fish was calculated as the time between the start of the experiment (June 10) and the date the fish was found dead. Mortality was identified by the presence of dead fish on the surface and bottom of the pond. To avoid errors in calculating mortality due to fish predation, anti-predator (birds) polypropylene screens $(2 \times 2 \mathrm{~cm}$ mesh) screens were installed on the ponds.

Samples of water were collected weekly to determine the concentration of ammonia, nitrate, nitrite, dissolved oxygen, total phosphorus, orthophosphate, chlorophyll $a$ and pheophytin. Water temperature of ponds was measured daily at $8 \mathrm{a} . \mathrm{m}$. using a Multi-parameter Water Analyzer (HI9146-04: Hanna Instruments, Brazil).

All handling of animals were performed according to standards established by the Ethics Committee on Animal Use of Faculty of Agrarian and Veterinary Sciences of UNESP (CEUA 04/12/2015).

\subsection{Statistical analysis}

The experimental design was completely randomized with 12 treatments in a factorial scheme ( 3 diets $\times 4$ genetic groups) and 2 

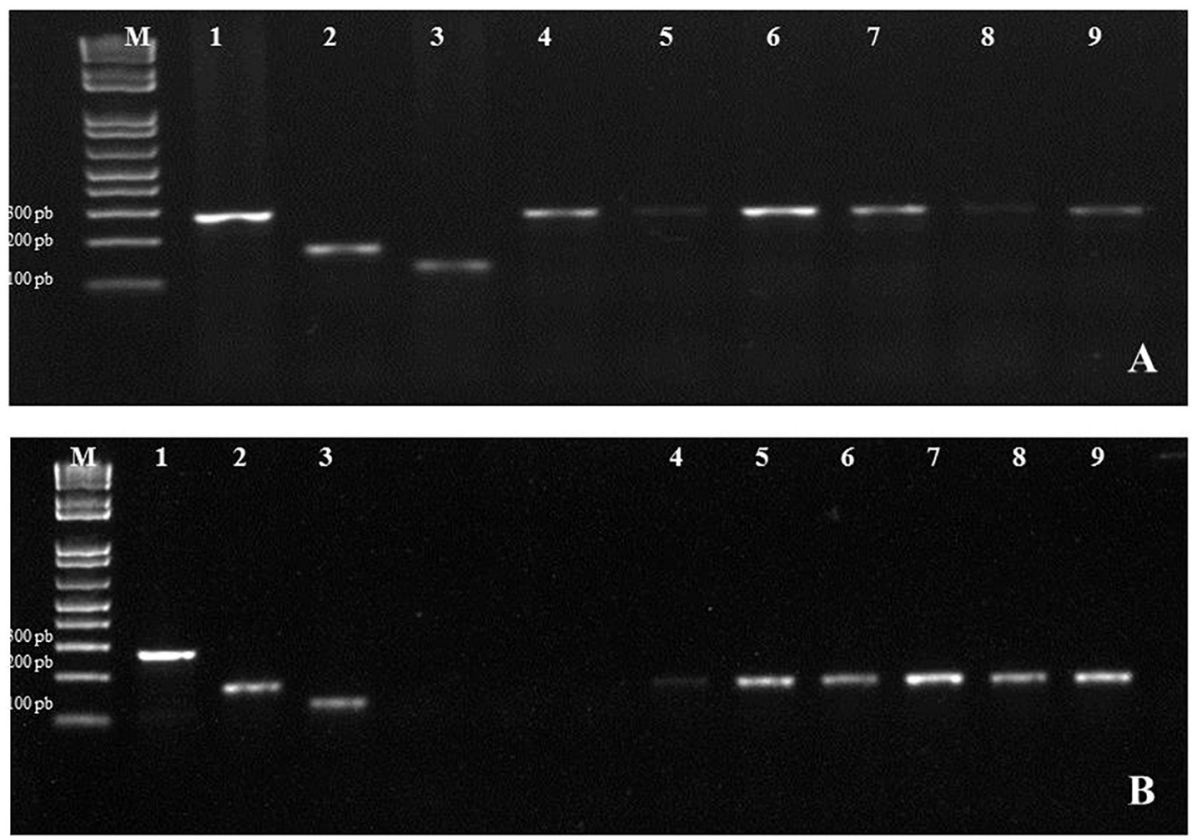

Fig. 1. A - Molecular identification pattern of Piaractus mesopotamicus stock of Caunesp. M, $1 \mathrm{~Kb}$ Plus DNA Ladder (Invitrogen); Columns 1, 2 and 3 are samples of purebred species $P$. mesopotamicus, $C$. macropomum and $P$. brachypomus, respectively, used controls for amplification; Columns 4, 5, 6, 7, 8 and 9 are samples of Piaractus mesopotamicus used as breeders for the experiment, whose purity was confirmed as having the same pattern as that found in column 1. B - Molecular identification pattern of Colossoma macropomum stock of Caunesp. M, $1 \mathrm{~Kb}$ Plus DNA Ladder (Invitrogen); Columns 1, 2 and 3 are samples of the purebred species $P$. mesopotamicus, C. macropomum and P. brachypomus, respectively, used as controls for amplification; Columns 4, 5, 6, 7, 8 and 9 are samples of Colossoma macropomum used as breeders for the experiment, whose purity was confirmed as having the same pattern as that found in column 2 . replicates per treatment.

The data on animal survival time (days) were submitted to Cox multivariate regression analysis (Cox, 1972) to test the effects of the genetic group, CP level in the diet and the interaction between the two factors on survival time using the "survival" library of statistical software R for windows, version 3.4.2 (R Core Team, 2013). Subsequently, survival curves were adjusted, based on the Kaplan-Meier method (Curve and Efron, 1988), for factors that had a significant effect on the Cox regression analysis. The lifetime estimates (in days) generated from the survival curves were compared for each adjustment set using the log-rank test whose statistics can be adjusted to a chi-square distribution. Since the test used was generalized for multiple comparisons, the value of $\alpha$ was corrected using the Bonferroni method in which the critical value is obtained by dividing $\alpha$ at $5 \%$ by the number of comparisons considered in each analysis.

\section{Results}

\subsection{Water quality}

The values of water quality variables remained within the standards of Conama (2005) for inland waters (Table 1). During the survival evaluation period, mean values for the water temperature ranged from $14.0{ }^{\circ} \mathrm{C}$ to $22.9^{\circ} \mathrm{C}$ (Fig. 2). The temperatures recorded were relatively low, as the experiment was conducted in the winter, which coincided

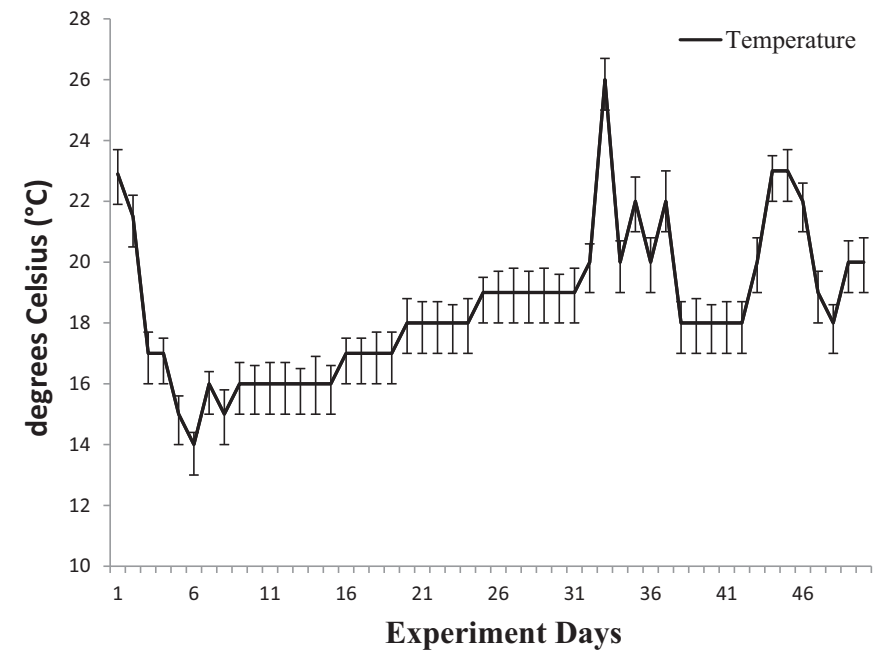

Fig. 2. Average and standard errors for water temperature of ponds during the survival evaluation period.

with the period of fish mortality.

The discarded fish presented typical symptoms of fungal infection, with changes in swimming behavior, lethargy, lesions on the tissues

Table 1

Mean values of Dissolved Oxygen ( $\left.\mathrm{mg} \mathrm{L}^{-1}\right)$, Hydrogenation Potential, Water Transparency $(\mathrm{cm})$, Electrical Conductivity $\left(\mu \mathrm{S} \mathrm{cm}^{-3}\right)$, Water Alkalinity $(\mathrm{mg}$ CaCO3 $\left.\mathrm{L}^{-1}\right)$, Total Ammoniacal Nitrogen $\left(\mathrm{Mg} \mathrm{L}^{-1}\right)$, Nitrite $\left(\mathrm{mg} \mathrm{L}^{-1}\right)$, Nitrate $\left(\mathrm{mg} \mathrm{L}^{-1}\right)$, Orthophosphate $\left(\mathrm{mg} \mathrm{L}^{-1}\right)$ and Total Phosphorus ( $\left.\mathrm{mg} \mathrm{L}^{-1}\right)$, during the experimental period in the twelve ponds.

\begin{tabular}{|c|c|c|c|c|c|}
\hline & Supply & $24 \%$ CP & $28 \% \mathrm{CP}$ & $32 \% \mathrm{CP}$ & Effluent \\
\hline Dissolved oxygen & $4.27 \pm 2.7$ & $5.77 \pm 1.9$ & $5.92 \pm 1.9$ & $5.73 \pm 1.6$ & $5.15 \pm 2.3$ \\
\hline $\mathrm{pH}$ & $5.82 \pm 0.6$ & $5.90 \pm 1.1$ & $5.96 \pm 0.9$ & $5.96 \pm 0.9$ & $5.96 \pm 1.1$ \\
\hline Alkalinity & $23.45 \pm 2.7$ & $21.99 \pm 3.4$ & $22.9 \pm 2.1$ & $22.28 \pm 2.3$ & $24.81 \pm 2.9$ \\
\hline Transparency & $100 \pm 0$ & $60 \pm 11,5$ & $60 \pm 12.5$ & $60 \pm 12.5$ & $100 \pm 0$ \\
\hline Conductivity & $51.15 \pm 1.6$ & $51.16 \pm 1.8$ & $49.4 \pm 2.1$ & $51.08 \pm 1.9$ & $49.70 \pm 1.9$ \\
\hline Total Am. Nitrogen & $0.001 \pm 0.0$ & $0.002 \pm 0.0$ & $0.002 \pm 0.0$ & $0.002 \pm 0.0$ & $0.002 \pm 0.0$ \\
\hline Nitrite & $0.000 \pm 0.0$ & $0.000 \pm 0.0$ & $0.000 \pm 0.0$ & $0.000 \pm 0.0$ & $0.000 \pm 0.0$ \\
\hline Nitrate & $0.021 \pm 0.0$ & $0.096 \pm 0.0$ & $0.057 \pm 0.0$ & $0.042 \pm 0.0$ & $0.0142 \pm 0.0$ \\
\hline Orthophosphate & $0.000 \pm 0.0$ & $0.000 \pm 0.0$ & $0.000 \pm 0.0$ & $0.000 \pm 0.0$ & $0.000 \pm 0.0$ \\
\hline Total Phosphorus & $0.001 \pm 0.0$ & $0.000 \pm 0.0$ & $0.000 \pm 0.0$ & $0.001 \pm 0.0$ & $0.001 \pm 0.0$ \\
\hline
\end{tabular}



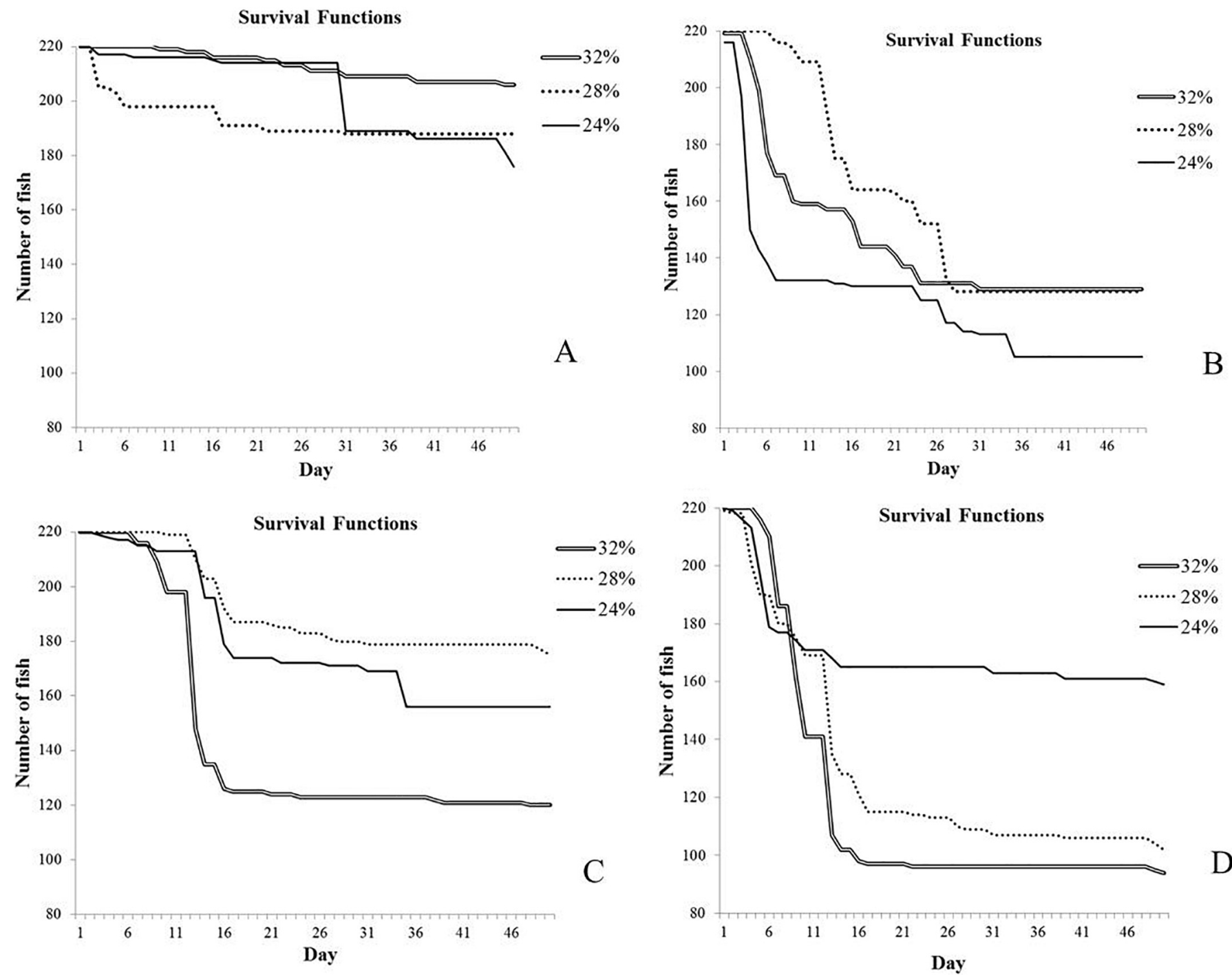

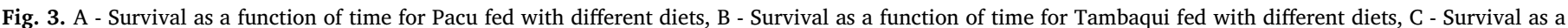
function of time for Tambacu fed with different diets, D - Survival as a function of time for the Paqui fed with the different diets.

(gills and skins) and necrosis, which are consequences of thermal stress associated to drop in fish immune system efficiency (Coelho et al., 2003).

\subsection{Survival analysis}

The Cox multivariate regression analysis showed a significant effect of the interaction, thus, there is dependence between the genetic group and the CP level of the diet for the survival of the animals.

Pacu juveniles fed with the $32 \% \mathrm{CP}$ diet had a higher survival rate $(p<.016)$ compared with pacu fed with other diets, and tambaqui fed with diets containing $32 \% \mathrm{CP}$ or $28 \% \mathrm{CP}$ showed a higher survival rate ( $\mathrm{p}<.016$ ) compared with tambaquis fed the $24 \%$ CP diet (Fig. 3, Table 2).

The relationship between survival and dietary protein level in hybrid juveniles was contrary to that in purebred juveniles. Tambacu fed with the $32 \% \mathrm{CP}$ diet had higher $(\mathrm{p}<.016)$ mortality compared with the tambacu fed with $28 \% \mathrm{CP}$ and $24 \% \mathrm{CP}$ diets, and paqui that consumed the diet with $24 \%$ CP showed longer $(\mathrm{p}<.016)$ survival time than paqui juveniles that consumed the diets containing $32 \%$ and $28 \%$ CP (Fig. 3, Table 2).

Thus, by analyzing the results for genetic groups singly as a function of the different diets, it was observed that a diet containing a higher
Table 2

Estimation (confidence interval) of expected lifetime (days) fish juveniles (pacu, tambaqui, tambacu and paqui) fed on diets with different protein levels.

\begin{tabular}{lllll}
\hline $\begin{array}{l}\text { Crude } \\
\text { protein } \\
\text { levels }\end{array}$ & Genetic groups & & & \\
\cline { 2 - 5 } & Pacu & Tambaqui & Tambacu & Paqui \\
\hline $32 \% \mathrm{CP}$ & 48.5 & 33.7 & $33.5(31-35.9)$ & $27.5(24.9-30)$ \\
& $(47.6-49.3)^{*} \mathrm{Aa}$ & $(31.1-36.4)$ & $\mathrm{Bb}$ & $\mathrm{Bc}$ \\
& & $\mathrm{Ab}$ & & \\
$28 \% \mathrm{CP}$ & $43.9(42-45.9)$ & 36.6 & 43.7 & 29.8 \\
& $\mathrm{Ba}$ & $(34.5-38.8)$ & $(41,9-45.4) \mathrm{Aa}$ & $(27.2-32.5) \mathrm{Bc}$ \\
& & $\mathrm{Ab}$ & & \\
$24 \% \mathrm{CP}$ & 43.9 & $36.6(26.3-32)$ & $43.7(39.1-43)$ & 29.8 \\
& $(45.3-47.7) \mathrm{Ba}$ & $\mathrm{Ab}$ & $\mathrm{Aa}$ & $(36.4-41.4) \mathrm{Bc}$ \\
\hline
\end{tabular}

Estimates followed by uppercase letters in the same column are significantly different according to the log-rank test $(p<.008)$. Estimates followed by lowercase letters in the same line are significantly different according to the log-rank test $(p<.0016)$. *(lower limit - upper limit).

protein level was more efficient for the purebred species, whereas the diet containing a lower protein level was more favorable for the hybrids. This finding explains the higher mortality of fish fed with a diet containing a higher protein level, since, in general, more hybrids (507 

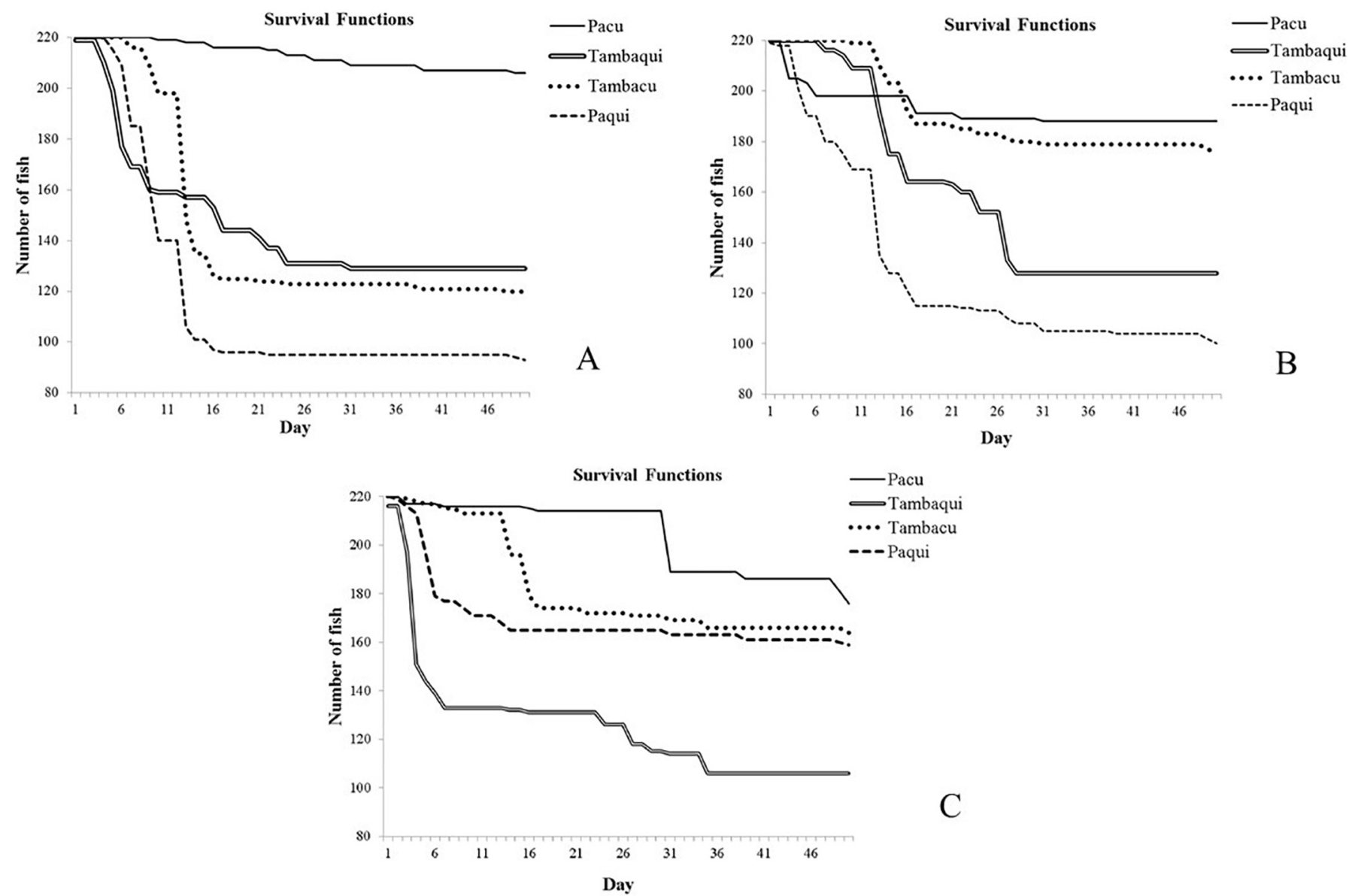

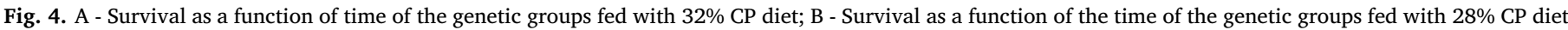
and C - Survival as a function of the time of the genetic groups fed with $24 \%$ CP diet.

or $39 \%$ of fish) than purebred fish died (388 or $30 \%$ of fish).

When feeding a diet containing $32 \% \mathrm{CP}$, it was observed that pacu was the group that achieved the highest $(p<.008)$ survival, whereas paqui was the group with the highest $(\mathrm{p}<.008)$ mortality. Survival time between tambaqui and tambacu showed no significant difference (Fig. 4, Table 2).

The pacu and tambacu groups, when fed with the $28 \%$ CP diet, showed higher survival $(\mathrm{p}<.008)$ than the other groups. Again, paqui was the group that presented the lowest survival $(\mathrm{p}<.008)$ when fed with the $28 \%$ CP diet (Fig. 4, Table 2).

With regard to the $24 \% \mathrm{CP}$ protein level diet, the pacu group had a greater $(\mathrm{p}<.008)$ survival, followed by the tambacu and paqui groups that did not differ $(p>.008)$ from each other. Tambaqui juveniles presented lower survival $(p<.008)$ than the other genetic groups (Fig. 4, Table 2), which resulted in a lower expected lifetime of purebreds when fed with a low protein diet.

In general, the pacu showed the same or higher level of tolerance to low temperatures than other genetic groups in all tests performed when exposed to a thermal challenge. Tambacu produced results equivalent to pacu with the $28 \%$ CP diet and equivalent to tambaqui with the $32 \%$ $\mathrm{CP}$ diet. Paqui were shown to be inferior, in terms of the tests performed in this study, to the other genetic groups (Table 2).

\section{Discussion}

The water quality parameters varied within acceptable levels for fish farming, as recommended by Conama (2005), except for the water temperature that fell below the temperatures recommended in the literature for tropical species.
Temperature variation potentially influences all fish physiological and behavioral processes (Lembi, 2001). According to Mazeaud et al. (1977), these changes in physiological and behavioral processes can be classified into three phases: the primary phase, characterized by the release of catecholamine and activation of the corticotropin-interrenal axis; the secondary phase, characterized by hematological, osmoregulatory, enzymatic and metabolic effects; and the tertiary phase, characterized by susceptibility to diseases such as those caused by fungi and bacteria, and lower growth and fecundity.

In our study, the water temperature showed abrupt drops varying from $14.0^{\circ} \mathrm{C}$ to $22.9^{\circ} \mathrm{C}$, which directly influenced the mortality of the genetic groups evaluated. After a temperature drop during the experimental period, fish of some genetic groups presented uncoordinated and slow swimming and could be captured by hand. Fungi were visible between the pectoral and dorsal fins, and there was appearance of necrosis on the skin. Studies involving tropical species have reported osmoregulatory disturbance, disorientation, imbalance and mortality at low temperatures (Sardella et al., 2007; Sun et al., 1992).

Among the purebred genetic groups, pacu were the least susceptible to temperature variation, regardless of the dietary protein level. This result was anticipated since the pacu habitat, the Pantanal - prata basin, is characterized by temperatures between $15^{\circ} \mathrm{C}$ and $35^{\circ} \mathrm{C}$, and the ideal temperature for pacu farming range from $20^{\circ} \mathrm{C}$ to $28^{\circ} \mathrm{C}$; below $18{ }^{\circ} \mathrm{C}$ or $19^{\circ} \mathrm{C}$, fish tends to cease feeding due to reduction in metabolic activity (Saint-Paul, 1986). Milstein et al. (2000) observed in their study that the low tolerance limit of pacu occurred between $7.0^{\circ} \mathrm{C}$ and $7.5^{\circ} \mathrm{C}$ when high mortality was reported. On the other hand, tambaqui were more susceptible to temperature variation. Unlike pacu, tambaqui is a native species from the Amazon basin where temperatures are higher, 
ranging from $25^{\circ} \mathrm{C}$ to $34^{\circ} \mathrm{C}$.

Considering the hybrid groups, the animals from the paqui group were less resistant to low temperature than animals from the tambacu group with all levels of $\mathrm{CP}$ in the diet. From the genetic point of view, the paqui group presented similar results to the tambaqui parental species, and tambacu presented similar results to the pacu parental species for adverse conditions throughout the experiment. This can be explained by traits that the parental species transmit to their progeny, that is, paternal and maternal effects. It was observed in the case of paqui that the pacu females did not transmit the rusticity displayed by purebred species, with the maternal effect being expressed to a lesser extent or even insignificant. However, there was a paternal effect of tolerance to low temperatures in tambacu, since these fish were more resistant than paqui to temperature drops. Reis Neto et al. (2012) also observed a paternal influence on body traits (carcass and visceral yields) of tambacu and paqui, and a maternal effect on the final weight and fillet yield of the hybrids.

Studies, such as Allaman et al. (2012), show the occurrence of a maternal and paternal effect on the fertilization rate, hatching rate and early growth in Curimba, Prochilodus lineatus. The success of fertilization and hatching are due more to the factors contained in the oocyte, such as nutrients and mitochondrial DNA that are influenced by the age, weight and condition of the mother, rather than due to factors in the semen (Garamszegi et al., 2007; Brown et al., 2006). Usually, maternal effect is considered in prediction models of breeding values in breeding programs for tilapia because it actually influences production traits (Khaw et al., 2016).

In general, tambaqui and paqui groups were more susceptible to low temperatures; this became more evident when the fish were fed with the diet containing a lower CP level (24\%) and can be attributed to the greater metabolic demand of these groups. Temperature can influence the protein requirement of the fish, since under temperatures of thermal comfort they require a greater supply of protein for maintaining physiological functions, benefiting more from the food consumed (Tung and Alfaro, 2011). Thus, low temperatures seem to affect the protein requirement of tambaqui and paqui more than the other groups and, therefore, the diet containing $24 \%$ CP did not provide sufficient nutrients to maintain the physiological condition of the fish at an adequate level.

\section{Conclusions}

The group that adapted best to the exposed environmental conditions was pacu, regardless of dietary protein level. However, if fish farmers opt for the production of hybrid fish, the tambacu (tambaqui female $\times$ pacu male) presents better tolerance to low temperatures. The low level of protein in the diet appears to contribute to the susceptibility of the less tolerant groups to low temperatures.

\section{Acknowledgements}

The authors are grateful to the São Paulo Research Support Foundation FAPESP (Process 2014/26339-7) for financial support and to the UNESP Aquaculture Center (CAUNESP) for the availability of the pacu and tambaqui breeding stock.

\section{References}

Allaman, I.B., Freitas, R.T.F., Viveiros, A.T.M., Nascimento, A.F., Oliveira, G.R., Neto, R.V.R., 2012. Efeito materno e paterno sobre as taxas de fertiliza????o e eclos??o em curimba (Prochilodus lineatus). Arq. Bras. Med. Vet. e Zootec. 64, 1584-1590. https://doi.org/10. 1590/S0102-09352012000600026.

Azevedo, P.A., Podemski, C.L., Hesslein, R.H., Kasian, S.E.M., Findlay, D.L., Bureau, D.P., 2011. Estimation of waste outputs by a rainbow trout cage farm using a nutritional approach and monitoring of lake water quality. Aquaculture 311, 175-186. https://doi.org/10.1016/j. aquaculture.2010.12.001.
Bicudo, A.J.A., Sado, R.Y., Cyrino, J.E.P., 2010. Growth performance and body composition of pacu Piaractus mesopotamicus (Holmberg 1887) in response to dietary protein and energy levels. Aquac. Nutr. 16, 213-222. https://doi.org/10.1111/j.1365-2095.2009.00653.x.

Brown, K.H., Lee, R.W., Thorgaard, G.H., 2006. Use of androgenesis for estimating maternal and mitochondrial genome effects on development and oxygen consumption in rainbow trout, Oncorhynchus mykiss. Comp. Biochem. Physiol. 143, 415-421.

Coelho, A.C., Fontaínhas-Fernandes, A., Santos, S., Cortes, R., Rodrigues, J., 2003. Mucormycosis due to Rhizopus sp. in fishes: first case described in Portugal. Arq. Bras. Med. Veterinária e Zootec. 55, 234-237. https://doi.org/10.1590/S010209352003000200019.

CONAMA, 2005. CONAMA - National Environment Council. Resolution nํㅜ 357, of March 17, 2005. Ministry of the Environment, 23p.

Cox, D.R., 1972. Models and life-tables regression. J. R. Stat. Soc. Ser. B 34, 187-220. https:// doi.org/10.1007/978-1-4612-4380-9_37.

Criscuolo-Urbinati, E., Kuradomi, R.Y., Urbinati, E.C., Batlouni, S.R., 2012. The administration of exogenous prostaglandin may improve ovulation in pacu (Piaractus mesopotamicus). Theriogenology 78, 2087-2094. https://doi.org/10.1016/j.theriogenology.2012.08.001.

Curve, K.-M., Efron, B., 1988. Logistic regression, survival analysis, and the. J. Am. Stat. Assoc. 83, 414-425.

Dayton, P.K., Thrush, S.F., Agardy, M.T., Hofman, R.J., 1995. Environmental effects of marine fishing. Aquat. Conserv. Mar. Freshw. Ecosyst. 5, 205-232. https://doi.org/10.1002/aqc. 3270050305.

Dobson, S.H., Holmes, R.M., 1984. Compensatory growth in the rainbow trout, Salmo gaivdnevi Richardson. J. Fish Biol 25, 649-656. https://doi.org/10.1111/j.1095-8649.1984. tb04911.x.

FAO, 2016. FAO fisheries \& aquaculture - home [WWW document]. State World Fish. Aquac 2016.

Filho, J.C., 2016. A produção aquícola de 2016. Dados do IBGE. Panor. da Aquicultura.

Garamszegi, L.Z., Biard, C., Eens, M., 2007. Maternal effects and the evolution of brain size in birds: overlooked developmental constraints. Neurosci. Biobehav. Rev, 31, 498-515.

Hashimoto, D.T., Senhorini, J.A., Foresti, F., Porto-Foresti, F., 2012. Interspecific fish hybrids in Brazil: management of genetic resources for sustainable use. Rev. Aquac. 4, 108-118. https://doi.org/10.1111/j.1753-5131.2012.01067.x.

Hashimoto, D.T., Senhorini, J.A., Foresti, F., Martínez, P., Porto-Foresti, F., 2014. Genetic identification of F1 and post-F1 serrasalmid juvenile hybrids in Brazilian aquaculture. PLoS One 9. https://doi.org/10.1371/journal.pone.0089902.

Hidalgo, F., Alliot, E., Thebault, H., 1987. Influence of water temperature on food intake, food efficiency and gross composition of juvenile sea bass, Dicentrarchus labrax. Aquaculture 64, 199-207. https://doi.org/10.1016/0044-8486(87)90325-5.

Jobling, M., Baardvik, B.M., 1994. The influence of environmental manipulations on inter- and intra-individual variation in food acquisition and growth performance of Arctic charr Salvelinus alpinus. J. Fish Biol. 44, 1069-1087. https://doi.org/10.1111/j.1095-8649.1994. tb01277.x.

Kellogg, R.L., Gift, J.J., 1983. Relationship between optimum temperatures for growth and preferred temperatures for the young of four fish species. Trans. Am. Fish. Soc. 112, 424-430. https://doi.org/10.1577/1548-8659(1983)112<424.

Khaw, H.L., Ponzoni, R.W., Yee, H.Y., Aziz, M.A. Bin, Bijma, P., 2016. Genetic and non-genetic indirect effects for harvest weight in the GIFT strain of Nile tilapia (Oreochromis niloticus). Aquaculture 450, 154-161. https://doi.org/10.1016/j.aquaculture.2015.07.033.

Lembi, C.A., 2001. Limnology, Lake and river ecosystems. J. Phycol. 37, 1146-1147. https:// doi.org/10.1046/j.1529-8817.2001.37602.x.

Lima, C.D.S., Bomfim, M.A.D., De Siqueira, J.C., Ribeiro, F.B., Lanna, E.A.T., 2016. Crude protein levels in the diets of tambaqui Colossoma macropomum (Cuvier, 1818), fingerllings. Rev. Caatinga 29, 183-190. https://doi.org/10.1590/1983-21252016v29n121rc.

Mazeaud, M.M., Mazeaud, F., Donaldson, E.M., 1977. Primary and secondary effects of stress in fish: some new data with a general review. Trans. Am. Fish. Soc. 106, 201-212 (10.1577 1548-8659(1977)106 < 201:PASEOS > 2.0.CO;2).

McCauley, R., Beitinger, T., 1992. Predicted effects of climate warming on the commercial culture of the channel catfish, Ictalurus punctatus. GeoJournal 28, 61-66. https://doi.org/ 10.1007/BF00216407.

Milstein, A., Zoran, M., Peretz, Y., Joseph, D., 2000. Low temperature tolerance of pacu Piaractus mesopotamicus. Environ. Biol. Fishes 58, 455-460. https://doi.org/10.1023/ a:1007672401544.

Ng, W.K., Lu, K.S., Hashim, R., Ali, A., 2000. Effects of feeding rate on growth, feed utilization and body composition of a tropical bagrid catfish. Aquac. Int. 8, 19-29. https://doi.org/10. 1023/A:1009216831360.

R Development Core Team, 2013. R: A language and environment for statistical computing. $\mathrm{R}$ Foundation for Statistical Computing (ISBN 3-900051-07-0 Vienna, Austria). http://www. R-project.org.

Reis Neto, R.V., Serafini, M.A., de Freitas, R.T.F., Allaman, I.B., Mourad, N.M.N., de Assis Lago, A., 2012. Performance and carcass traits in the diallel crossing of pacu and tambaqui1. Rev. Bras. Zootec. 41, 2390-2395. https://doi.org/10.1590/S1516-35982012001200002.

Saint Paul, U., 1986. The neotropical Serrasalmid Colossoma macropomum: a promising species for fish culture in Amazonia. Analysis Research and Development, Hamburg 22 (1), 7-35.

Sardella, B.A., Matey, V., Brauner, C.J., 2007. Coping with multiple stressors: physiological mechanisms and strategies in fishes of the Salton Sea. Lake Reserv. Manag. 23, 518-527. https://doi.org/10.1080/07438140709354035.

Sipaúba-Tavares, L.H., Moraes, M.A., De, G., Braga, F.M., S, D., 1999. Dynamics of some limnological characteristics in pacu (Piaractus mesopotamicus) culture tanks as function of handling. Rev. Bras. Biol. 59, 543-551. https://doi.org/10.1590/S003471081999000400003

Sun, L.-T., Chen, G.-R., Chang, C.-F., 1992. The physiological responses of tilapia exposed to low temperatures. J. Therm. Biol. 17, 149-153. https://doi.org/10.1016/0306-4565(92) 90026-C.

Tung, C.H., Alfaro, A.C., 2011. Effect of dietary protein and temperature on the growth and health of juvenile New Zealand black-footed abalone (Haliotis iris). Aquac. Res. 42, 366-385. https://doi.org/10.1111/j.1365-2109.2010.02631.x. 